\title{
The Correlation Between Loneliness and Academic Procrastination Among Psychology Students at State University of Malang
}

\section{Muhammad Khairul Anam*, and Imanuel Hitipeuw}

Faculty of Psychology Education, State University of Malang, Malang, Indonesia ORCID

Muhammad Khairul Anam; https://orcid.org/0000-0002-1031-3620

\begin{abstract}
One of the problems that often occurs when completing a thesis is academic procrastination. This can result in delayed graduation, which is not desirable in our education system. Loneliness can affect students' academic performance. Globally, loneliness has been increasing as a result of the COVID-19 pandemic. Students who are working on their thesis are vulnerable to loneliness. This research aimed to determine whether there is a correlation between loneliness and procrastination among psychology students who are working on their thesis. This research used descriptive quantitative methods, and data were obtained from online questionnaires that were distributed to 55 psychology students working on a thesis at the State University of Malang. Participants were recruited through convenience sampling. The research instruments used were two modified scales: the Loneliness Scale created by de Jong-Gierveld and Kamphuls ( $\alpha=0.796)$ [1] and the Academic Procrastination Scale created by McCloskey and Scielzo $(\alpha=0.905)$ [2]. The data were analyzed with the Pearson Product Moment correlation test. The results showed that there was a weak but significant and positive correlation between loneliness and academic procrastination $(r=319 ; p<0.05)$. Most research subjects had a moderate level of loneliness and academic procrastination.
\end{abstract}

Corresponding Author:

Muhammad Khairul Anam; email: muh.khairul.anam.1708116@ students.um.ac.id

Dates

Published 28 January 2022

Publishing services provided by Knowledge

(c) Muhammad Khairul Anam, and Imanuel Hitipeuw. This article is distributed under the terms of the Creative Commons Attribution License, which permits unrestricted use and redistribution provided that the original author and source are credited

Selection and Peer-review under the responsibility of the ICoPsy Conference Committee.

\section{G OPEN ACCESS}

Keywords: Ioneliness, academic procrastination, correlation

\section{Introduction}

Completing academic tasks is something that a student will always face. Tasks that are not completed properly will affect the academic performance of students. The problem that often afflicts students in completing academic tasks well is academic procrastination [3][4][5]. Poor academic performance is certainly something that is not desirable in our education world. Procrastination is one that is still a student problem when dealing with thesis [6][7]. Procrastination is an increasingly widespread phenomenon spreading in the academic sphere, $70-95 \%$ of undergraduate students are estimated to be involved in procrastination [8]. Academic procrastination by students causes students to delay their graduation. Based on the observations of researchers, approximately 10 students in 
the class of 2017 faculty of psychological education, Universitas Negeri Malang (FPPsi UM) alone successfully conducted a hearing as of May 31, 2021, in semester 8 . The number indicates a delay, inaction, or delay in the thesis work carried out by students. This problem can be categorized as academic procrastination. Judging by its definition, academic procrastination is one of the unique forms of procrastination tendencies and refers to students who voluntarily delay completing academic assignments [2].

COVID-19 has affected various aspects of human life, not least the world of education. One of the impacts of COVID-19 on education is the occurrence of global loneliness [9]. Loneliness that occurs either due to the COVID-19 pandemic or not meeting students with college friends due to online learning or other factors that cause loneliness can affect the psychological condition of students. If not handled properly, this can affect the academic performance of students. In fact, long before the occurrence of COVID-19, students already had various academic problems.

Loneliness can be one of the obstacles for students to complete a thesis. Feelings of a lack of quality social relationships or the perception that social relationships do not meet individual needs may indicate loneliness [10][11]. The dissatisfaction that individuals experience when closeness is reduced with other individuals can also be called loneliness [12]. Since 2020, the phenomenon of loneliness occurs and spread throughout the world. This came to be known as global loneliness, a phenomenon of loneliness in the world associated with the COVID-19 pandemic. There is another term that also follows this phenomenon, namely epidemic loneliness. This global loneliness phenomenon occurs by involving different layers of age, culture, and gender [9]. Not only at the national level, but the whole world is experiencing this one form of loneliness. Of course, this phenomenon of loneliness does not escape also occurs in academic circles, in this case students.

Preliminary study results conducted by researchers found that 9 psychology students in 2017 at FPPsi UM admitted to experiencing loneliness and academic procrastination either at the same time or not. The preliminary study conducted was an initial interview by conveying some short questions to 2017 students at FPPsi UM. From the interview it was found that academic procrastination conducted was caused by lack of support, laziness, pressure from friends around(insecure), feeling lonely because the time to gather with friends was reduced, COVID-19 which became a limit to meet physically, difficulty meeting a guidance lecturer, reference materials that are difficult to find, feeling saturated because every day is overwhelmed by unfinished thesis proposals, feeling anxious, and moods that continue to change with each other. 


\section{Literature Review}

Academic procrastination is a form of procrastination tendency and refers to when students voluntarily delay the completion of academic-related tasks such as working on task projects and studying [13]. Academic procrastination can also occur because of tasks that accumulate too much and must be done immediately. The execution of one task may cause another task to be delayed [14]. Aspects of academic procrastination can be divided into six, namely: psychological confidence in ability, attention disorders, social factors, time management abilities, personal initiative, and laziness [13].

Loneliness is a state of negative emotion caused by perceptions of unmet social needs [15]. Loneliness is an individual's subjective feeling due to the absence of relationships [16]. These conditions can be temporary circumstances caused by drastic changes in an individual's social life. Emotional loneliness is caused by a failure to establish attachment in relationships and a failure to integrate socially. Loneliness can also be interpreted as a situation experienced by individuals who get certain relationship qualities that are unpleasant or inappropriate [17]. There are two aspects of loneliness based on the loss of certain social conditions experienced by individuals are emotional loneliness and social loneliness [18] [27]. Emotional loneliness or emotional loneliness is an aspect of loneliness that occurs due to the absence of a figure who becomes a cherished mooring. The absence of a close affection figure such as parents to children and close friends to someone. Meanwhile, social loneliness or social loneliness is an aspect of loneliness explained by a lack of friends and associations. Loss of sense of social integration in friendship groups or co-workers.

\section{Method}

This research is a correlational quantitative research using population from all psychology students who are working on a thesis at the State University of Malang with a total sample of 55 respondents using the convenience sampling technique. Data are collected by using online questionnaires. The research instruments used are the modification of Loneliness Scale by de Jong-Gierveld and Kamphuls [1] with high reliability $(\alpha=0.796)$ with 11 items and a modification of Academic Procrastination Scale (APS) by McCloskey and Scielzo [2] with very high reliability $(\alpha=0.905)$ with 15 items. 
TABLE 1: Statistics Descriptive $(\mathrm{N}=55)$.

\begin{tabular}{l|l|l|} 
& Loneliness & \multicolumn{1}{c}{ Academic Procrastination } \\
\hline Mean & 32.036 & 50.818 \\
\hline Std. Deviation & 6.686 & 8.468 \\
\hline Minimum & 16.000 & 32.000 \\
\hline Maximum & 45.000 & \\
\hline
\end{tabular}

TABLE 2: Loneliness Data.

\begin{tabular}{l|l|l} 
Category & Frequency & Percentage \\
Low & 8 & 14.5 \\
Moderate & 39 & 70.9 \\
High & 8 & 14.5 \\
\hline
\end{tabular}

\section{Result and Discussion}

The subjects numbered 55 people who were psychology students who were working on a thesis in the class of 2017 at Malang State University. Data collection includes the names/initials, gender, and year of the respondent's class. Data collection was conducted on July 27,2021 , to July 29,2021 . An overview of the characteristics of study respondents was presented in the form of frequency of gender, class, loneliness, and academic procrastination. The results of the gender frequency calculation showed that of the 55 respondents there were 17 men (30.9\%) and 38 women (69\%).

The results of the descriptive analysis showed that of the 55 respondents, the average loneliness score was 32,036 included in the moderate category with a standard deviation of 6,686 and the average academic procrastination score was 50,818 included in the moderate category with a standard deviation of 8,486 . On lonely scores, the lowest score is 16 and the highest score is 45 . The results of the descriptive analysis are listed in Table 1.

The picture of loneliness in psychology students who are working on a thesis at Malang State University can be seen in the results of the categorization of loneliness data. The results of the categorization of loneliness data showed a moderate tendency. The loneliness data also showed that out of 55 respondents there were 8 respondents with low levels of loneliness, 39 respondents with moderate levels of loneliness, and 8 respondents with high levels of loneliness. The results of the categorization of loneliness data are listed in Table 2.

Loneliness that occurs in psychology students who are working on thesis is also in line with research that states that many in early adulthood experience an increase in 
TABLE 3: Academic Procrastination Data.

\begin{tabular}{l|l|l} 
Category & Frequency & Percentage \\
Low & 1 & 1.8 \\
\hline Moderate & 35 & 63.6 \\
High & 19 & 34.5 \\
\hline
\end{tabular}

TABLE 4: Hypothesis Testing.

\begin{tabular}{|c|c|c|c|c|c|}
\hline \multicolumn{6}{|c|}{ Pearson Correlations } \\
\hline & & & \multicolumn{2}{|c|}{ Pearson's r } & p \\
\hline Loneliness & - & Academic Procrastination & 0.319 & * & 0.018 \\
\hline
\end{tabular}

Ioneliness [9]. This moderate-prone loneliness can be explained as follows: First, a relationship that has a deficiency or not adequate can cause a person to be dissatisfied with the relationship they have. Various reasons individuals experience loneliness, namely: the absence of bonding, ignored, middle alone, forced isolation, and moving locations of residence [19]. This happens because individuals are experiencing isolation due to several forms of adaptation during pandemics, namely: PPKM, physical distancing, restriction of individual mobility, and must survive in the role.

An overview of the level of academic procrastination in psychology students who are working on thesis at Malang State University can be seen in the results of categorization of academic procrastination data. The results of categorization of academic procrastination data show a moderate trend. Academic procrastination data also showed that out of 55 respondents there was 1 respondent with a low level of academic procrastination, 35 respondents with a moderate level of academic procrastination, and 19 respondents with a high level of academic procrastination. The results of the categorization of academic procrastination data are listed in Table 3.

Pearson's correlation analysis results showed that there was a significant positive relationship between loneliness and academic procrastination with $r=, 319 ; p<.005$. These results also indicate a relationship with moderate strength. Thus, it can be concluded that the hypothesis that has been established by the researcher is accepted with $\mathrm{H}_{1}$ accepted and $\mathrm{H}_{0}$ rejected. If the level of loneliness is high, then the level of academic procrastination will also be high and vice versa.

The results of this study are in line with previous research conducted by Andangsari and colleagues who mentioned that loneliness is one of the causes of academic procrastination [20]. This suggests a link between loneliness and academic procrastination, even to the degree of fullness. The results of the study strengthened scientific 
findings related to the correlational relationship between loneliness and academic procrastination.

The results of this study are also supported by research that states that there is a relationship between loneliness and procrastination academic [21]. Loneliness as one of the psychosocial problems that cause academic procrastination. This reinforces the work of psychosocial syndemic theory on academic procrastination which states that the existence of more than one psychosocial problem can increase the emergence of academic procrastination. Shi and colleagues believe that individuals with high levels of loneliness are likely to have friends the same age who can act as mentors or figures who supervise individuals so as not to experience procrastination [21]. The results of his study also showed a correlation between the two variables [21].

Individuals who do not have adequate social relationships can cause individuals to experience loneliness and academic procrastination [19][21]. This social factor makes individuals with high loneliness which means not having adequate social relationships and not having people closest to them. This can cause individuals to experience academic procrastination due to the absence of a close figure that can help individuals keep from academic procrastination [21][22]. Various reasons individuals have inadequate relationships, namely: the absence of bonding, ignored, middle alone, forced isolation, and moving residences [19]. This happens because individuals are experiencing isolation caused by several forms of adaptation during pandemics, namely: PPKM, physical distancing, restrictions on individual mobility, and must survive in the roles described above. In addition, interpersonal individuals with loneliness tend to have low self-esteem, have negative attitudes to others and lack in social abilities. This leads to social rejection that can make individuals feel lonely. The absence of a social environment leads to the absence of those closest to them who can guard individuals against academic procrastination [21].

Loneliness can be the reason for time management problems, interpersonal relationships, and health problems [13][23]. Time management, interpersonal relationships, and physical health problems are factors that cause academic procrastination in individuals. Loneliness also affects individual decision-making thus disrupting initiatives that can be undertaken by individuals [13][24]. Initiative is also one aspect of academic procrastination. This may explain the relationship between loneliness and academic procrastination [13]. One of the contributing factors to academic procrastination is physical health [25]. Physical health problems are the impact of loneliness on individuals [24]. Physical health problems that occur due to loneliness can give rise to academic procrastination. Loneliness is also an antecedent (clinical aspect) of the rise of academic procrastination [26]. 
Individuals who experience loneliness also have impaired concentration and attention where individuals are more focused on building social relationships than choosing to do their academic tasks [20][28]. All of the above exposures can well explain the relationship between loneliness and academic procrastination in psychology students who are working on a thesis at Malang State University.

\section{Acknowledge, Funding, \& Ethics Policies}

The author thanked the Faculty of Psychological Education at the State University of Malang who had organized the International Conference of Psychology 2021 so that this article can be disseminated and receive more benefits.

\section{References}

[1] de Jong-Gierveld J, Kamphuls F. The development of a rasch-type loneliness scale. Applied Psychological Measurement. 1985;9(3):289-299. https://doi.org/10.1177/014662168500900307

[2] McCloskey J, Scielzo SA. Finally! The development and validation of the academic procrastination scale.Researchgate [Preprint]. Cited 2021 March 2. Available from: https://www.researchgate.net/profile/ShannonScielzo/publication/273259879_Finally_The_Development_and_Validation_of_the_Acade The-Development-and-Validation-of-the-Academic-Procrastination-Scale.pdf DOI:10.13140/RG.2.2.23164.64640

[3] Day V, Mensink D, O'Sullivan M. Patterns of academic procrastination. Journal of College Reading and Learning. 2000;30(2):120-134.

[4] Goroshit M, Hen M. Academic procrastination and academic performance: Do learning disabilities matter? Current Psychology. 2021;40(5):2490-2498. https://doi.org/10.1007/s12144-019-00183-3

[5] Schraw G, Wadkins T, Olafson L. Doing the things we do: A grounded theory of academic procrastination. Journal of Educational Psychology. 2007;99(1):12-25. https://doi.org/10.1037/0022-0663.99.1.12

[6] Loren A, Madyan M, Afriansyah A. Pengaruh dukungan sosial teman terhadap prokrastinasi dalam menyelesaikan skripsi pada mahasiswa angkatan 2017 fakultas dakwah uin sts jambi [Undergraduate Thesis]. Jambi: UIN Sulthan Thaha Saifuddin Jambi; 6281798032021628179803srobona gdastidar628179803664515292Location of publisher. 
[7] Setyani LA. Hubungan stres akademik dengan prokrastinasi akademik pada mahasiswa dalam menyusun skripsi saat pandemi Covid-19 [Undergraduate Thesis]. Banyumas: Universitas Jenderal Soedirman; 6281798022021628179802srobona gdastidar628179802664515296Location of publisher.

[8] Klassen RM, Krawchuk LL, Rajani S. Academic procrastination of undergraduates: Low self-efficacy to self-regulate predicts higher levels of procrastination. Contemporary Educational Psychology. 2008;33(4):915-931. https://doi.org/10.1016/j.cedpsych.2007.07.001

[9] Barreto M, Victor C, Hammond C, Eccles A, Richins MT, Qualter P. Loneliness around the world: Age, gender, and cultural differences in loneliness. Personality and Individual Differences. 2021;628179801169628179801srobona gdastidar628179801664515287Page numbers(Feb $2021) 110066$. https://doi.org/10.1016/j.paid.2020.110066

[10] Bareket-Bojmel L, Shahar G, Abu-Kaf S, Margalit M. Perceived social support, loneliness, and hope during the COVID-19 pandemic: Testing a mediating model in the UK, USA, and Israel. British Journal of Clinical Psychology. 2021;60(2):133-148. https://doi.org/10.1111/bjc.12285

[11] Cao Q, Lu B. Mediating and moderating effects of loneliness between social support and life satisfaction among empty nesters in China. Current Psychology. 2021;40(2):110. https://doi.org/10.1007/s12144-018-0019-0

[12] de Jong Gierveld J, van Tilburg T. The De Jong Gierveld short scales for emotional and social loneliness: Tested on data from 7 countries in the UN generations and gender surveys. European Journal of Ageing. 2010;7(2):121-130. https://doi.org/10.1007/s10433-010-0144-6

[13] McCloskey JD. 628179800Finally, my thesis on academic procrastination [Graduate Thesis].628179800srobona gdastidar628179800664515292Type of thesis, name and location of publisher Arlington: THE UNIVERSITY OF TEXAS AT ARLINGTON. 2011.

[14] Burka J, Yuen LM. Procrastination: Why you do it, what to do about it now. Boston: Da Capo Lifelong Books; 6281797992007628179799srobona gdastidar628179799664515287Location of publisher.

[15] Cacioppo JT, Hawkley LC. Loneliness. In M. R. Leary \& R. H. Hoyle (Eds.), Handbook of individual differences in social behavior (pp. 227-240). New York:The Guilford Press. 6281797982009628179798srobona gdastidar628179798664515288Name and location of publisher. 
[16] Russell D, Peplau LA, Ferguson ML. Developing a measure of Ioneliness. Journal of Personality Assessment. 1978;42(3):290-294. https://doi.org/10.1207/s15327752jpa4203_11

[17] de Jong-Gierveld J. Personal relationships, social support, and loneliness. Journal of Social and Personal Relationships. 1989;6(6281797972628179797srobona gdastidar628179797664515288Page numbers)197-221. https://doi.org/10.1177/026540758900600204

[18] Sadler WA, Weiss RS. Loneliness: The experience of emotional and social isolation. Contemporary Sociology. 1975;4(2):239-240. https://doi.org/10.2307/2062224

[19] Miller RS, Perlman D, Brehm SS. Intimate relationships. Boston: McGraw-Hill Higher Education; 2007.

[20] Andangsari EW, Djunaidi A, Fitriana E, Harding D. Loneliness and problematic internet use (PIU) as causes of academic procrastination. International Journal of Social Science Studies. 2018;6(6281797962628179796srobona gdastidar628179796664515286Page numbers)113. https://doi.org/10.11114/ijsss.v6i2.2834

[21] Shi X, Wang S, Liu S, Zhang T, Chen S, Cai Y. Are procrastinators psychologically healthy? Association between psychosocial problems and procrastination among college students in Shanghai, China: A syndemic approach. Psychology, Health and Medicine. 2019;24(5):570-577. https://doi.org/10.1080/13548506.2018.1546017

[22] Reasinger R, Brownlow S. Putting off until tomorrow what is better done today: Academic procrastination as a function of motivation toward college work. Journal of Social Behavior and Personality. 2000;15(5):15-34.

[23] Bozoglan B, Demirer V, Sahin I. Loneliness, self-esteem, and life satisfaction as predictors of internet addiction: A cross-sectional study among Turkish university students. Scandinavian Journal of Psychology. 6281797952013628179795srobona gdastidar628179795664515287Volume, issue and page numbers;54(4)313-319. https://doi.org/10.1111/sjop.12049

[24] Hämmig O. Health risks associated with social isolation in general and in young, middle and old age. PLoS ONE. 6281797942019628179794srobona gdastidar628179794664515291Volume, issue and page numbers; 14(7)e0219663. https://doi.org/10.1371/journal.pone.0219663

[25] Ferrari JR, Johnson JL, McCown WG. Procrastination and task avoidance: Theory, research, and treatment. Berlin: Springer Science \& Business Media; 6281797931995628179793srobona gdastidar628179793664515290Location of publisher. 
[26] Steel P, Klingsieck KB. Academic procrastination: Psychological antecedents revisited. Australian Psychologist. 2016;51(1):36-46. https://doi.org/10.1111/ap.12173

[27] Jong-Gierveld J, van Tilburg T. The partner as source of social support in problem and non-problem situations. Journal of Social Behavior and Personality. 1987;6281797922628179792srobona gdastidar628179792664515291Page number(2)191-200.

[28] Perlman D, Peplau L. Toward a social psychology of loneliness. Personal Relationships. 1981;3:31-56. 